\section{LITERATURE AND SCIENCE}

Science and Criticism

The Humanistic Tradition in Contemporary Thought. By Herbert J. Muller. (Dwight Harrington Terry Foundation: Lectures on Religion in the Light of Science and Philosophy.) Pp. xiv +303 . (New Haven, Conn.: Yale University Press; London : Oxford University Press, 1943.) 25s. net.

DROF. MULLER, who is a professor of English, is perturbed at the incoherence and lack of standards in modern literature and modern life; as well he may be. He here expounds and criticizes (with good knowledge, sound sense and a pretty wit) many recent scientific theories in all branches, apparently because he thinks a better knowledge of them would improve literary standards. It is almost as though he thought "Macbeth" would be improved by substituting three psycho-analysts for the witches, or "Paradise Lost" by introducing Einstein's theory and the expanding universe.

Perhaps this is a parody of Prof. Muller's intentions. He says himself that he has tried "to make really available, for the purposes of literary criticism, the revolutionary findings in the natural and social sciences, with which critics are generally familiar but of which they make only superficial, incidental or erratic use". If this means anything it can be applied to a concrete case. From the preface to Shaw's "Doctor's Dilemma" it can be seen that his knowledge of medical science is less than superficial because he misconceives the whole character of scientific investigation. Nevertheless the play portrays excellently the contrasts between the medical humbug, the surgical 'go-getter' and two types of honest medical man. Shaw is a good enough observer to reproduce the general flavour of current medical jargon and that was all the technical knowledge he needed. Could any amount of medical knowledge have made any appreciable improvement ? As to literary criticism, do critics differ in their judgment of this play according to the extent of their medical knowledge? Surely the knowledge Shaw chiefly needed was of the difference between an honest man and a humbug; knowledge outside the scope of science. It is remarkable that the feeblest character in the "Doctor's Dilemma" is the young artist, who is just stock stage property.

Prof. Muller has been strongly influenced by the philosophy of Dewey and shares his robust good sense, proper suspicion of high-flown theory and respect for the factual and concrete. But even more than Dewey he is shaky on fundamentals. Though he has acute criticisms to make of some recent advocates of 'scientific humanism', he seems to share their inability to distinguish between matters of fact and standards or criteria of value. In literary criticism he obviously has standards which are not those of the average man or the majority, nor are they just expressions of private likes and dislikes. $\mathrm{He}$ gives no account of his own standards, but it is clear (pp. 1, 47 note, 283 and elsewhere) that for him they are absolute. Yet, when it comes to other people's absolutes and standards, he takes a severely 'relativist' and 'naturalist' view, urging that every judgment is relative to a particular concrete situation, that nothing has value except to some individual who values it, that it is difficult to define standards of value, perhaps impossible. All these assertions are correct; but if they suffice to demolish other people's standards they demolish his own. Confusion about standards seems to be the key to the writing of this book. The author sees that literary judgments are too often based on caprice or convention or defiance of convention that is equally conventional ; that literary standards are hard to discover and impossible to define. Science, on the other hand, seems to possess its own standards, definite and easily understood. Therefore if only the literary man could borrow scientific standards all would be well.

Literary men may learn from this book that if they ride scientific hobby-horses they do so at their own risk, but scarcely anything else. Men of science may benefit by learning what an intelligent, critical outsider thinks of some of their activities. Those who theorize in the realm of the social sciences may benefit by some wholesome criticism.

\section{A. D. Ritchie.}

\section{A TEXT-BOOK OF ZOOLOGY}

Thomson's Outlines of Zoology

Revised by Prof. James Ritchie. Ninth edition. Pp. xiit-1021. (London: Oxford University Press, 1944.) 28s. net.

THE ninth edition of the "Outlines of Zoology" appears after a lapse of fifteen years, and is the first since Sir Arthur Thomson's death. In the preface, Prof. James Ritchie expresses his appreciation of the opportunity afforded to him of paying a tribute to his former teacher "by endeavouring to prolong the usefulness of his widely known Outlines". He was assisted by Dr. Gresson and Mr. G. F. Friend.

In considering a new edition, as opposed to a new book, three questions confront the reviewer. Does the new edition preserve the original character of the book? Have the emendations been fitted into the whole so that the balance has been preserved and overburdening of the text avoided? Has the subject-matter been brought up to date? The outstanding feature of Sir Arthur Thomson's book was that the blending of animal structure and function with a broader 'natural history' made the book readable, and presented the subject to the student so pleasantly that it encouraged him to explore both the main site and the nooks and corners of this vast field of study. Prof. Ritchie has preserved and improved this feature and his re-arrangements do not disturb the flow of thought. His emendations and additions concern chiefly the portions on cytology, histology, embryology and palæontology, while nearly a hundred new drawings, lettered with complete words instead of abbreviations, have been inserted, or used to replace earlier figures. All this has been done without disturbance of the balance of the book.

The cytology section has been modermized; but is it not generally recognized to-day that the chromo. somes persist through the resting stage of the nucleus ? In the short portions of chapters devoted to embryology more recent work and better figures might have been utilized; for example, Conklin's researches on the origin and development of the mesoderm in Branchiostoma, and the interpretation of cinematograph studies of the primitive streak area in the chick.

On the whole, however, the new edition can be regarded as a most successful effort. Its bulk has been increased only slightly by the addition of about fifty pages, but the price has risen considerably. Despite the latter drawback, the book remains a rich source of information, and should prove useful to many generations of students. N. B. EALES. 